\title{
Jordskcelv i Skåne - kraftige rystelser i Danmark
}

Af Tine B. Larsen, Peter H. Voss og Søren Gregersen, GEUS

En helt almindelig søvnig vintermorgen, d.16. december 2008, blev tusindvis af danskere vækket ca. kl. 6.20 af de uvante rystelser fra et jordskælv. Huse knagede, ting og sager raslede, senge svajede og uhyggelige lyde hørtes fra undergrunden. Nogle steder var oplevelsen så intens, at forskrækkede mennesker løb udenfor - ganske som man bør, hvis man pludselig befinder sig midt i et kraftigt jordskælv.

Men jordskælvet var heldigvis helt ufarligt. Det havde sit epicenter nær den skånske by Sjöbo, ca. 60 km øst for Malmö, og det målte blot 4,8 på Richterskalaen. Rystelserne forplantede sig dog effektivt til Danmark, hvor især københavnere og nordsjællændere fik sig en ufrivillig gyngetur. I timerne og dagene efter jordskælvet indsamlede GEUS flere tusinde rapporter fra borgere, som

Kort over kendte forkastninger $i$ Danmark og tilgrænsende områder. De røde prikker viser, hvorfra GEUS modtog de første 3.000 rapporter om jordskcelvet $d .16$. december 2008. Epicentret er markeret med en gul prik. (Copyright: Kort fra Google Earth med indtegnet grafik af Peter $H$. Voss, GEUS)

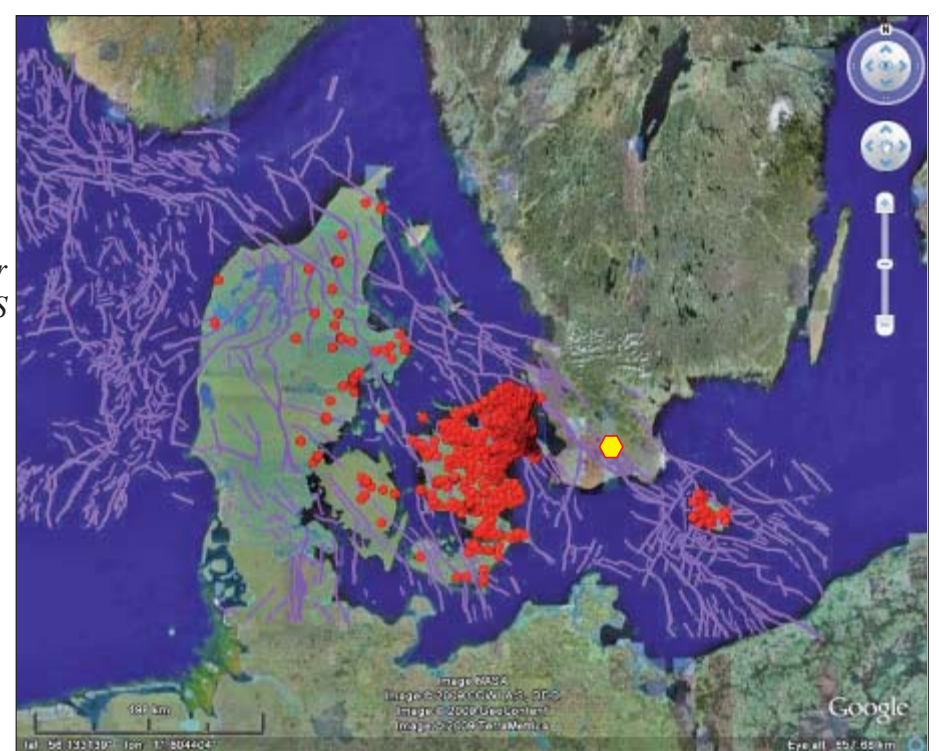

havde mærket jordskælvet. Øjenvidneberetningerne er et vigtigt redskab til at afdække rystelsernes intensitet i forskellige områder af landet.

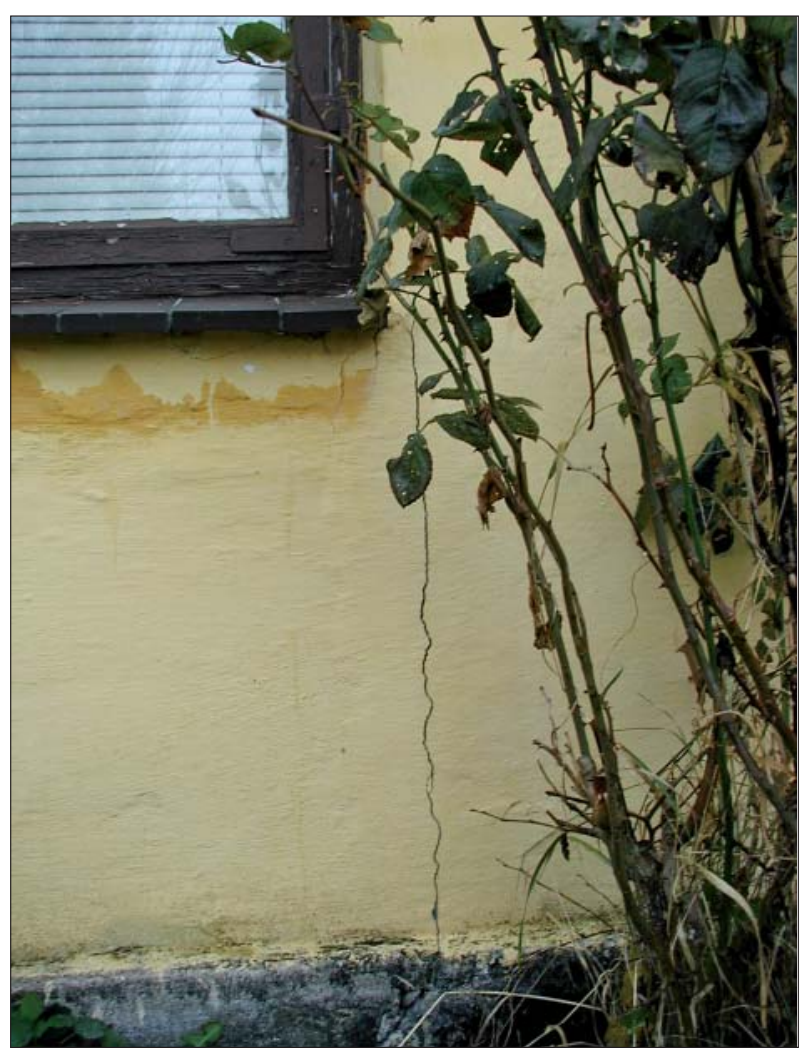

Billedet viser en pudsrevne, der opstod $i$ et hus på Vestsjelland i forbindelse med et jordskcelv d. 6. november 2001. Der er tale om et meget gammelt hus, som havde en hel del revner i forvejen. (Foto: Tine B. Larsen, GEUS)
Slumrende forkastninger - eller? Jordskælvet ved Sjöbo var usædvanligt kraftigt for området, men små jordskælv forekommer med mellemrum, selvom vi normalt betragter både Sverige og Danmark som tektonisk meget stabile. Den opfattelse har Skåne-jordskælvet ikke ændret ved. I perioden 1970 til 2008 blev der i Skåne registreret blot tre andre jordskælv, som alle var mindre end 3 på Richterskalaen.

Jordskælvets epicenter ligger i Sorgenfrei-Tornquist Zonen (STZ), som adskiller det prækambriske skjold mod nord og øst fra Centraleuropas yngre lithosfære mod syd. Selvom STZ udgør et imponerende system af gamle forkastninger, er jordskælvsaktiviteten langs zonen meget begrænset. Det er faktisk kun i Kattegat, der er overbevisende tegn på aktivitet i zonen. Længere mod syd, fx i Skåne, kan man ikke sige, at nogen af forkastningerne i STZ er aktive. Et enkelt jordskælv i STZ som det d. 16. december 2008 rokker ikke ved den opfattelse.

Beregningen af små jordskælvs epicentre er behæftet med en betydelig usikkerhed, i dette tilfælde på $6 \mathrm{~km}$. Så selvom der er kortlagt flere forkastninger i området (figuren ovenfor), er det umuligt at afgøre, om en af disse var ansvarlig for jordskælvet. Jordskælvets dybde er endnu dårligere bestemt på grund af områdets meget varierede geologi og ligger muligvis dybere end forkastningerne er kortlagt. 


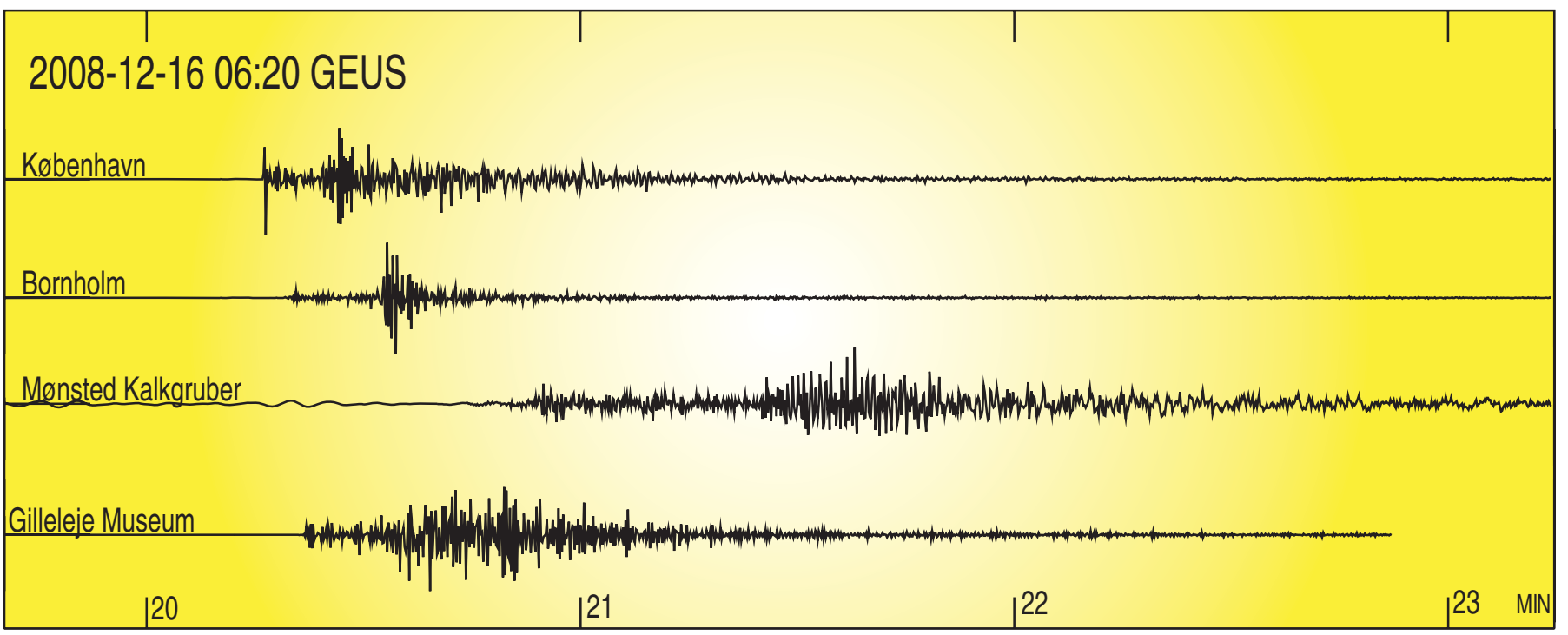

Seismogrammer fra GEUS' målestationer i Danmark. Seismogrammerne viser, hvordan jorden bevcegede sig op og ned under jordskcelvet. Rystelserne rammer først København, derefter Gilleleje og Bornholm og til sidst Mønsted. Rystelserne er 29 sekunder om at nå fra København til Mønsted Kalkgruber. Afstanden fra jordskcelvets epicenter til målestationerne er: København 66 km, Gilleleje 92 km, Bornholm 96 km og Mønsted 283 km. (Grafik: Peter H. Voss, GEUS)

Nordeuropa er under konstant pres fra den midtatlantiske ryg, og det skaber et spændingsfelt langt ind i pladen. I Skandinavien spiller spændingsfeltet fra den Midtatlantiske Ryg sammen med spændingerne fremkaldt af de sidste rester af landhævningen efter istiden. Af og til giver undergrunden efter for disse spændinger, og det er således jordskælvene i Danmark og Sverige opstår. Jordskælvene udløses, hvor der er svagheder i undergrunden, og det er ikke altid i nærheden af kendte forkastninger.

\section{Værdifulde beretninger}

Rystelserne fra et jordskælv forstærkes eller dæmpes af et områdes helt lokale geologi og jordbundsforhold. Byggestil spiller også en væsentlig rolle for, hvor kraftigt rystelserne mærkes. Således forstærkes rystelser i høje bygninger, og svage jordskælv mærkes kun af personer, som befinder sig flere etager oppe.

Når et jordskælv mærkes over et større område af Danmark, har vi en enestående chance for at identificere steder, hvor rystelserne i særlig grad forstærkes. Den viden kan anvendes til risikovurdering, hvis der på et senere tidspunkt skal bygges fx en større bygning eller bro. Ved risikovurderinger ser vi bort fra beretninger fra høje bygninger, således at det alene er effekten fra undergrunden, vi får frem.

Det er nødvendigt at indsamle øjenvidnerapporter på en ensartet form i forbindelse med jordskælv. Til det brug har GEUS udviklet et web-baseret spørgeskema, som lægges på hjemmesiden, når der er sket et jordskælv (se spørgeskemaet på næste side). Tidligere sendte vi spørgeskemaer ud med almindelig post, men det var ikke nær så effektivt. I forbindelse med jordskælvet $d$. 16. december har GEUS indsamlet over
4.000 rapporter, hvilket er næsten 10 gange så mange som ved det sidste store jordskælv i 1985 i Kattegat.

De mange rapporter om, hvordan jordskælvet blev oplevet - også i forhold til lokaliteten, vil blive plottet ind på et kort sammen med tilsvarende oplysninger fra Sverige, Nordtyskland og Polen, hvor Skånejordskælvet også blev følt. Dette kort vil så blive sammenlignet med de tilsvarende kort for alle tidligere jordskælv i regionen. De historiske oplysninger får ved denne sammenligning forøget værdi for bedømmelsen af jordskælvsaktiviteten og dermed risikoen i vores område.

Jordskcelv kan fortcelle os om retningen på spcendingerne i undergrunden, og hvilken type spcendinger der er tale om. I Danmark er vi udsat for sammenpresning fra den Midtatlantiske Ryg, men stressfeltet i Danmark, Norge og Sverige viser ikke kun sammenpresning fra ryggen. Der foregår stadig landhcevning som konsekvens af istidens ophør, og de spcendinger, som landhrevningen forårsager, giver et noget mere rodet stressfelt. (Grafik: UVH modificeret efter $S$. Gregersen, 1992)

\section{Min seng rystede!}

De indsamlede øjenvidneberetninger er ikke kun nyttige, men også fascinerende læsning. Rigtigt mange mennesker oplevede, at deres møbler rystede - sengen de lå i eller stolen de sad på. Samtidig var der en raslen og klirren fra skabe og vinduer, og i nogle tilfælde blev koncerten akkompagneret af dybe lyde fra undergrunden. I København og Nordsjælland var det for mange en skræmmende oplevelse, mens intensiteten var noget lavere i resten af landet.

Heldigvis skete der ingen større skader i forbindelse med jordskælvet. Nogle huse fik fremskyndet mindre sætningsrevner 
Jordskælvet den (dag/måned/år)

Det har stor interesse at få bestemt, hvor kraftigt jordskælvet har været mærket i forskellige om råder. Vi beder dig derfor om at besvare nedenstående spørgsmål og indsende skemaet til:

GEUS, Geofysisk Afdeling, Att: Seismologisk Tjeneste, Øster Voldgade 10, 1350

Navn

Adresse

evt.telefonnummer

Adresse hvor du befandt dig under jordskælvet

Var du inde eller ude?

Hvis inde, på hvilken etage af huset?

Opgiv dato og klokkeslet som du bedst husker det

Hvad var du i gang med da du mærkede jordskælvet?

Var du straks klar over, at det var jordskælv? Eller hvad troede du?

Hvordan mærkede du jordskælvet? Som en gyngende bevægelse, stød eller rystelse? $\mathrm{M} æ$ rkede du det flere gange, og i så fald med hvor store mellemrum?

Hvad var det første, du gjorde?.

Var der ting der klirrede eller raslede?

Porcelæn? ................. Vinduer?

Andet?

Knagede det i huset?

Hørte du i øvrigt nogen lyd fra jordskælvet?

Hvilken retning kom lyden fra?

Skete der skade på huset?

Hvilket materiale er huset primært bygget af? (mursten, beton, træ, etc.)

Hvor mange etager har huset?

Hvornår (ca.) er huset bygget?

Så du ting der svingede (f.eks. lamper)?

Så du direkte flytning af løse genstande?

I hvilken retning var bevægelsen?

Hvor langt blev tingen flyttet?

Hvor mange fra samme hus har du talt med om jordskælvet?

Hvor mange af disse havde mærket jordskælvet?

Hvor mange fra nabolaget har du talt med om jordskælvet?

Hvor mange af disse havde mærket jordskælvet?

Har du yderligere oplysninger? (f.eks. navn og adresse på andre, som har mærket jordskælvet)

Har du tidligere oplevet tilsvarende rystelser?

Hvor?

Hvornår?

Hvilken af rystelserne var kraftigst?

Tak for hjæIpen! 
og pudsskader, som tidens tand ville have været lidt længere om at fremkalde. Der var rapporter om friske revner i asfalten i en vej ved Helsingør, men efter inspektion af vejen, finder vi det mere sandsynligt, at revnerne er opstået som følge af kraftig trafik og ikke i forbindelse med jordskælvet.

\section{Danske jordskælv}

Der er jordskælv i Danmark hvert år, men de fleste jordskælv er så små, at de kun opfanges af seismograferne. Med få års mellemrum hænder det, at et jordskælv er kraftigt nok til, at også mennesker kan mærke det. Vi har dog ingen grund til at tro, at der pludselig kommer et kraftigt jordskælv i Danmark, for vi mangler de kræfter, der kan opbygge det nødvendige spændingsfelt i undergrunden. Der er størst chance for at opleve et dansk jordskælv, hvis man bor i Nordjylland eller i Nordsjælland.

Lœes mere om jordskcelv på: www.geus.dk

og følg med i de svenske jordskcelv på snsn.geofys.uu.se

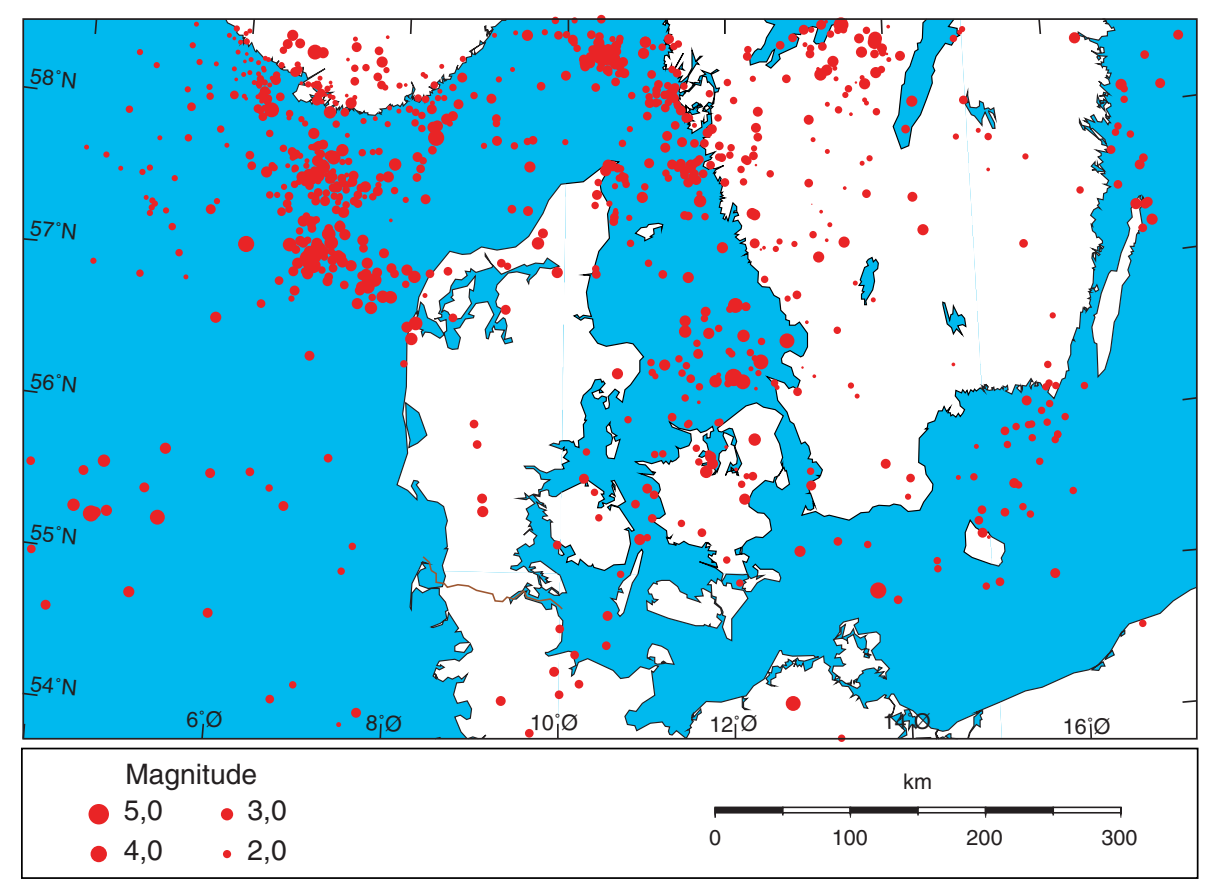

Kortet viser samtlige jordskcelv, som er registreret i Danmark og ncermeste omegn i perioden 1970 til 2008. Langt de fleste af jordskcelvene er for små til, at mennesker kan mcerke dem. (Grafik: GEUS) 